\title{
Nilai Haugh Unit (HU), Indeks Kuning Telur (IKT) dan Ph Telur Itik Pengging Setelah Pemberian Tepung Daun Kelor (Moringa oleifera Lam.)
}

\section{Haugh Unit (HU) Value, Egg Yolk Index (IKT), and pH of Pengging Duck Eggs after giving Moringa oleifera Leaf Flour}

\author{
Susan Nuraeni ${ }^{1}$, M. Anwar Djaelani ${ }^{2 *}$, Sunarno $^{2}$ dan Kasiyati ${ }^{2}$ \\ ${ }^{1}$ Program Studi Biologi, Fakultas Sains dan Matematika Universitas Diponegoro, Semarang \\ ${ }^{2}$ Departemen Biologi Fakultas Sains dan Matematika Universitas Diponegoro, Semarang \\ *E-mail: muhammadanwardjaelani@ rocketmail.com
}

Diterima 23 Mei 2019 / Disetujui 30 Juli 2019

\begin{abstract}
ABSTRAK
Itik lokal banyak dibudidayakan sebagai penghasil telur. Daun kelor (Moringa oleifera) mengandung nutrisi esensial, seperti asam amino dan protein yang berpotensi meningkatkan kualitas telur, terutama telur itik. Penelitian ini bertujuan untuk menganalisis pengaruh tepung daun kelor terhadap kualitas fisik telur itik pengging. Penelitian menggunakan rancangan acak lengkap (RAL) dengan 5 perlakuan dengan 4 ulangan, yaitu kelompok kontrol dan kelompok perlakuan pakan basal dengan tambahan tepung daun kelor 2,5; 5; 7,5; dan $10 \%$. Parameter yang diamati pada penelitian ini yaitu nilai Haugh unit (HU), indeks kuning telur (IKT), dan $\mathrm{pH}$ telur. Sampel diambil setiap hari kemudian dikumpulkan dan dilakukan pengukuran. Data yang diperoleh dianalisis mengunakan analysis of variance (ANOVA), apabila terdapat beda nyata antar perlakuan dilakukan uji lanjut dengan uji Duncan pada taraf kepercayaan 95\%. Hasil analisis menunjukan bahwa pemberian tepung daun kelor dalam pakan itik memberikan pengaruh yang nyata $(\mathrm{P}<0,05)$ pada nilai $\mathrm{HU}$ dan $\mathrm{pH}$ putih telur, namun tidak berpengaruh $(\mathrm{P}>0,05)$ pada IKT, $\mathrm{pH}$ kuning telur, dan bobot telur. Berdasarkan nilai $\mathrm{HU}$, telur pada penelitian ini dikategorikan dalam kualitas AA, dan $\mathrm{pH}$ putih telur tertinggi terdapat pada perlakuan $10 \%$ dengan nilai 8,66 . Berdasarkan penelitian tersebut dapat disimpulkan bahwa pemberian tepung daun kelor 7,5\% dapat meningkatkan kualitas telur tanpa merubah bobot telur.
\end{abstract}

Kata kunci: Itik pengging, daun kelor, kualitas telur

\section{ABSTRACT}

Local ducks are widely cultivated as egg producers. Moringa oleifera leaves contain essential nutrients, such as amino acids and proteins needed to improve egg quality. The objective of this study to analyze the effect of Moringa leaf flour on the physical quality of Pengging duck eggs. The study used a complete rendomized design (CRD) with 5 treatments with 4 replications, which consisted of control ( $0 \%$ of Moringa flour), and basic feed groups with the addition of Moringa leaf flour by 2,5; 5; 7,5; and $10 \%$. The parameters measured in this study are Haugh unit value (HU), egg yolk index, and egg $\mathrm{pH}$. Data obtained were analyzed using analysis of variance (ANOVA) follow by Duncan test with a significantly difference of $95 \%$. The results of the study showed that the addition of Moringa leaf flour in duck feed gave a significant different in HU values and $\mathrm{pH}$ of egg white, but did not significantly different in egg yolk index, $\mathrm{pH}$ of egg yolk, and egg weight. The Haugh Unit in this study can classified as AA grade, and the egg white $\mathrm{pH}$ in group of Moringa leaf flour with concentration of $10 \%$ was 8.66 . Based on this study it could be concluded that $7.5 \%$ Moringa leaf flour can improve egg quality without change of egg weight.

Keywords: Pengging duck, Moringa leaf flour, egg quality

\section{PENDAHULUAN}

Itik lokal merupakan salah satu plasma nutfah ternak Indonesia. Pelestarian dan pengembangan itik lokal harus diupayakan guna mempertahankan keberadaan plasma nutfah ternak 
Indonesia yang telah beradaptasi dengan lingkungan setempat (Ismoyowati, 2008). Populasi ternak unggas secara nasional pada tahun 20162018 mengalami peningkatan dibandingkan dengan populasi ternak unggas pada tahun 2015, yaitu sebanyak $4,64 \%$ dari jumlah sebelumnya (Ditjen PKH, 2017). Ternak itik mempunyai kelebihan diantaranya adalah memiliki daya tahan yang cukup baik terhadap penyakit. Oleh karena itu, usaha ternak itik memiliki risiko yang relatif lebih kecil sehingga sangat potensial untuk dikembangkan (Nugraha dkk., 2013).

Itik petelur banyak dibudidayakan oleh masyarakat untuk memenuhi kebutuhan protein hewani. Sebagian besar masyarakat mengkonsumsi telur sebagai bahan makanan untuk memenuhi kebutuhan nutrisinya karena telur merupakan bahan makanan yang mudah diperoleh dan mudah dalam pengolahan (Sudaryani, 2006). Kualitas telur dipengaruhi oleh faktor fisik dan kimiawi antara lain lama penyimpanan, nutrisi yang terkandung pada pakan, dan strain. Kualitas telur yang baik dapat dilihat dari karakteristik fisik, yaitu indeks kuning telur (IKT), indeks putih telur (IPT), haugh unit (HU), persentase bobot putih telur, persentase bobot kuning telur, warna kuning telur, indeks bentuk telur, bobot telur, dan indeks kerabang telur (Saraswati and Tana, 2016).

Pakan merupakan salah satu faktor eksternal yang mempengaruhi pertumbuhan dan produksi ternak. Berbagai jenis tanaman herbal digunakan untuk meningkatkan kualitas pakan. Salah satu jenis tanaman herbal yang banyak digunakan sebagai imbuhan bahan pakan adalah kelor (Moringa oleifera Lam.). Tanaman kelor merupakan salah satu jenis tanaman tropis yang mudah tumbuh di daerah tropis seperti Indonesia. Salah satu kandungan bioaktif tanaman kelor adalah antioksidan yang banyak ditemukan pada bagian daunnya (Aminah dkk., 2015). Secara in vitro kandungan antioksidan yang dimiliki tanaman kelor memiliki efek yang lebih baik daripada vitamin $\mathrm{E}$ dan menghambat peroksidasi lemak dengan cara memecah rantai radikal peroksil. Fenolik juga secara langsung menghambat reactive oxygen species (ROS) seperti hidroksil, superoksida, dan peroksinitit (Chumark et al., 2007).
Berdasarkan penelitian yang dilakukan Ahmad et al., (2017) pemberian tepung daun kelor pada pakan dengan konsentrasi 0,50\% meningkatkan berat telur menjadi $63,69 \mathrm{~g}$ dan meningkatkan indeks kuning telur menjadi 35,66. Pemberian tepung daun kelor dengan konsentrasi 1,5\% meningkatkan nilai HU menjadi 87,31. Nutrisi yang terkandung pada daun kelor, antara lain kalsium, besi, protein, vitamin A, vitamin B, dan vitamin C (Misra et al., 2014). Daun kelor mengandung unsur besi lebih tinggi dibandingkan sayuran lainnya, yaitu sekitar 17,2 mg/100 g (Yameogo et al., 2011). Daun kelor mengandung berbagai macam asam amino antara lain aspartat, glutamat, alanin, valin, leusin, isoleusin, histidin, lisin, arginin, fenilalanin, triptofan, sistein, dan metionin (Aminah dkk., 2015). Berdasarkan kandungan daun kelor dan manfaat daun kelor yang terlibat di dalam metabolisme maka penting sekali dilakukan penelitian ini. Tujuan dari penelitian ini adalah mengetahui pengaruh tepung daun kelor pada kualitas fisik telur pengging yang meliputi nilai HU, IKT, bobot telur, dan $\mathrm{pH}$ telur.

\section{METODE PENELITIAN}

Penelitian dilakukan di dua tempat berbeda. Penelitian untuk pemeliharaan itik lokal bertempat di Peternakan rakyat di Dukuh Kalijaran, Desa Bawak, Cawas Klaten. Analisis IKT, pH telur serta nilai HU dilaksanakan di Laboratorium Biologi Struktur dan Fungsi Hewan, Departemen Biologi Fakultas Sains dan Matematika Universitas Diponegoro.

\section{Alat dan Bahan}

Alat-alat yang digunakan dalam penelitian ini adalah kandang itik sebanyak 15 petak yang berukuran $100 \times 150 \times 70 \mathrm{~cm}^{3}$, tempat pakan itik, tempat minum itik, ember, kaca, neraca digital ukuran gram, timbangan, alat bedah, jangka sorong (caliper), kertas label, kertas $\mathrm{pH}$, lateks, masker, solet, dan mangkok. Bahan yang digunakan dalam penelitian ini adalah itik lokal betina berjumlah 60 ekor berumur 24 minggu, tepung daun kelor yang diperoleh dari Flozindo Purbalingga, dedak, pakan 
konsentrat, kabel ties, sekam padi, tisu, tusuk gigi, dan air.

\section{Cara Kerja}

\section{Persiapan kandang dan hewan uji}

Kandang penelitian dibuat dengan ukuran $100 \times 150 \times 70 \mathrm{~cm}^{3}$ berupa sistem litter dengan alas sekam padi. Setiap kandang diberikan sekat menggunakan bilah bambu/kayu. Masing-masing kandang diisi dengan 4 ekor itik. Hewan uji berupa itik pengging betina sebanyak 60 ekor dengan bobot 1.500-1.600 g. Itik yang digunakan berumur 24-26 minggu.

\section{Pembuatan pakan}

Pakan itik yang digunakan selama penelitian berbentuk mash semibasah yang sudah diformulasikan dengan tepung daun kelor. Pakan itik telah disesuaikan dengan kebutuhan nutrisi itik petelur periode produksi atau periode dewasa kelamin (>24 minggu) (Kasiyati et al., 2019). Komposisi bahan pakan dan kandungan nutrisi pakan itik petelur periode produksi disajikan pada Tabel 1.

Tabel 1. Komposisi bahan pakan dan kandungan nutrisi pakan itik petelur periode produksi

\begin{tabular}{llllll}
\hline \multirow{2}{*}{ Bahan pakan (\%) } & \multicolumn{5}{c}{ Konsentrasi tepung daun kelor (\%) } \\
\cline { 2 - 6 } & $0 \%$ & $2,5 \%$ & $5 \%$ & $7,5 \%$ & $10 \%$ \\
\hline Dedak padi & 60 & 60 & 60 & 60 & 60 \\
Konsentrat * & 40 & 37,5 & 35 & 32,5 & 30 \\
Tepung daun kelor & 0 & 2,5 & 5 & 7,5 & 10 \\
Total & 100 & 100 & 100 & 100 & 100 \\
Kandungan nutrisi hasil analisi laboratorium & & & & \\
Energi metabolis (kkal/kg) & 2630,50 & 2680,90 & 2790,57 & 2840,80 & 2880,45 \\
protein kasar (\%) & 17,22 & 17,56 & 18,30 & 19,56 & 20,08 \\
Lemak (\%) & 6,16 & 5,40 & 5,25 & 4,25 & 4,16 \\
Kalsium (\%) & 1,82 & 2,05 & 2,56 & 2,90 & 3,04 \\
Serat kasar (\%) & 3,07 & 3,25 & 3,57 & 4,09 & 4,21 \\
\hline *Konsentrat untuk bebek petelur diperoleh dari pabrik pakan ternak, mengandung protein kasar 37\%, \\
lemak kasar 3,5\%, serat kasar 6\%, kalsium 13-14\%, fosfor 14,18\%, dan abu 40\%.
\end{tabular}

\section{Manajemen pemeliharaan}

Itik ditempatkan ke dalam 20 buah petak kandang untuk diaklimasi selama satu minggu. Masing-masing petak kandang berisi 4 ekor itik, setiap ekor itik diberi tanda pada pergelangan kaki menggunakan kabel ties bewarna (putih, merah, hitam, dan biru). Pemberian pakan dan minum disediakan ad libitum pada pagi dan sore hari.

\section{Perhitungan Parameter}

Penentuan nilai HU sesuai dengan Badan Standar Nasional (2008), yaitu :

$$
\mathrm{HU}=100 \log \left(\mathrm{H}+7,57-1,7 \mathrm{~W}^{0.37}\right)
$$

Keterangan :

$$
\begin{array}{ll}
\mathrm{HU} & =\text { Haugh unit } \\
\mathrm{H} & =\text { tinggi albumen }(\mathrm{mm}) \\
\mathrm{W} & =\text { bobot telur }(\mathrm{g})
\end{array}
$$

Berdasarkan Badan Standar Nasional Indonesia (2008), nilai IKT dapat diperoleh dari rumus:

$$
\mathrm{IKT}=\frac{\text { tinggi kuning telur }(\mathrm{mm})}{\text { diameter kuning telur }(\mathrm{mm})}
$$

\section{Perhitungan Bobot telur}

Bobot telur itik diperoleh dengan cara menimbang telur menggunakan timbangan digital dengan kepekaan 0,1 g (Purwati dkk., 2015). pH kuning dan putih telur diukur menggunakan kertas $\mathrm{pH}$ yang dicelupkan pada masing-masing bagian 
putih dan kuning telur, kemudian dibaca sesuai dengan perubahan warna indikator.

\section{Rancangan Penelitian}

Rancangan penelitian yang digunakan adalah rancangan acak lengkap (RAL) dengan 5 perlakuan dan 4 ulangan. Perlakuan antara lain K0 (pakan basal), K1 (pakan basal $+2,5 \%$ tepung daun kelor), K2 (pakan basal $+5 \%$ tepung daun kelor), K3 (pakan basal $+7,5 \%$ tepung daun kelor), K4 (pakan basal $+10 \%$ tepung daun kelor). Data yang diperoleh dianalisis menggunakan ANOVA dengan signifikasi $5 \%$ dan dilanjutkan dengan uji Duncan pada taraf kepercayaan $95 \%$.

\section{HASIL DAN PEMBAHASAN}

Kualitas telur itik pengging dapat dilihat secara fisik, yaitu dengan mengetahui nilai $\mathrm{HU}$, IKT, dan $\mathrm{pH}$ telur. Hasil analisis kualitas fisik telur berupa HU, IKT, bobot telur, tinggi putih telur, tinggi kuning telur, dan diameter kuning telur setelah pemberian tepung daun kelor (M. oleifera) selama 3 minggu dapat dilihat pada Tabel 2. Nilai HU mengindikasikan kualitas fisik putih telur itik dan IKT menunjukkan kualitas fisik kuning telur itik pengging.

Hasil analisis pemberian tepung daun kelor sebagai imbuhan pakan itik pengging selama 3 minggu terhadap nilai Haugh unit (HU) menunjukkan berbeda nyata $(\mathrm{P}<0,05)$. Nilai $\mathrm{HU}$ berbeda nyata pada perlakuan tepung daun kelor 5\% dibandingkan dengan kontrol, tepung daun kelor $7,5 \%$, dan tepung daun kelor $10 \%$, namun tidak ada perbedaan nyata antara perlakuan tepung daun kelor 5\% dengan daun kelor 2,5\%. Nilai HU yang dihasilkan pada penelitian ini adalah 83,2389,34, putih telur masih berada dalam kondisi segar dan tergolong dalam kualitas AA. Standar kualitas telur berdasarkan USDA (2000) menyatakan bahwa nilai $\mathrm{HU}$ dikatorikan ke dalam 4 grade, yaitu kualitas AA adalah telur yang memiliki nilai $\mathrm{HU}>72$, kualitas $\mathrm{A}$ adalah telur yang memiliki nilai HU 60-72, kualitas B adalah telur dengan nilai HU 31-60, dan kualitas $\mathrm{C}$ adalah telur dengan nilai $\mathrm{HU}<31$. Nilai $\mathrm{HU}$ pada penelitian ini juga memiliki korelasi positif dengan tinggi putih telur $(r=0,87)$. Hal ini dapat diartikan bahwa peningkatan tinggi putih telur berkontribusi pada peningkatan nilai HU. Sesuai dengan pernyataan Saraswati dan Tana (2016) bertambahnya tinggi putih telur maka nilai $\mathrm{HU}$ akan tinggi pula.

Tepung daun kelor pada konsentrasi kelor $5 \%$ memberi pengaruh nyata $(\mathrm{P}<0,05)$ terhadap nilai HU yang lebih rendah dibandingkan dengan kontrol dan perlakuan lainnya. Nilai $\mathrm{HU}$ yang dihasilkan pada kelor 5\% lebih rendah $6,84 \%$ jika dibandingkan dengan nilai HU kelompok kontrol. Kondisi ini diduga berkaitan dengan kandungan bahan aktif kelor berupa tanin yang dominan bekerja pada konsentrasi 5\% memiliki efek memperlambat proses metabolisme. Gangguan proses metabolisme berdampak pada penurunan energi dan produktivitas (Sunarno, 2018). Susetyarini (2013) menyatakan bahwa beberapa tanin mempunyai aktivitas antioksidan yang mampu menghambat pertumbuhan tumor dan enzim seperti reverse transcriptase dan DNA topoisomerase, selain itu tanin juga mampu menghambat terjadinya proses sintesis protein.

Tanin merupakan suatu zat anti-nutrisi. Penambahan tanin pada pakan unggas dapat memberikan efek anti-nutrisi yang menyebabkan penurunan kecernaan bahan organik dan dapat mengakibatkan menurunnya pertumbuhan atau produksi telur (Minieri et al., 2016). Hal tersebut sejalan dengan penelitian yang dilakukan oleh Kwari et al. (2011), bahwa pemberian pakan yang mengandung tanin menurunkan produksi telur, berat telur, dan kualitas kerabang telur jika dibandingkan dengan perlakuan kontrol. Berdasarkan Griffiths (1986), pemberian tanin pada pakan menghambat beberapa enzim pencernaan diantaranya enzim tripsin, amilase, dan lipase yang menyebabkan menurunnya ketersediaan protein. Hal ini sejalan dengan Tamir and Alumot (1969), yang menyatakan bahwa tanin paling sensitif menghambat amilase dan yang paling tidak sensitif menghambat lipase.

Pemberian tepung daun kelor juga menunjukkan hasil yang berbeda nyata $(\mathrm{P}<0,05)$ pada tinggi putih telur. Tinggi putih telur pada kelompok kontrol menunjukan berbeda nyata $(\mathrm{P}<0,05)$ dengan kelompok imbuhan tepung daun kelor 2,5\% dan kelor 5\%. Tinggi putih telur pada konsentrasi tepung daun kelor 5\% lebih rendah $10,9 \%$ jika dibandingkan dengan tinggi putih pada 
perlakuan kontrol, sedangkan untuk tinggi putih telur pada konsentrasi tepung daun kelor 2,5\% lebih rendah $8,62 \%$ jika dibandingkan dengan kontrol. Hal ini diduga karena keberadaan bahan aktif pada daun kelor konsentrasi 2,5 dan 5\% menyebabkan penghambatan proses metabolisme di dalam tubuh yang berpotensi menyebabkan gangguan penyediaan substrat metabolisme. Bahan aktif berupa tanin yang terkandung pada konsentrasi 2,5 dan 5\% diduga mampu menghambat metabolisme tubuh, sehingga menyebabkan nilai $\mathrm{HU}$ pada konsentrasi 2,5\% rendah. Hal ini sesuai dengan pernyataan Gilani et al. (2005), tanin yang terkondensasi maupun yang terhidrolisis memiliki kemampuan mengendapkan protein, sehingga memiliki sifat sebagai antinutrisi.
Tanin dalam konsentrasi tertentu dapat mengurangi kecernaan protein, karbohidrat, mineral, dapat menurunkan aktivitas enzim pencernaan, dan dapat menyebabkan kerusakan sel-sel pencernaan sehingga proses metabolisme tubuh menjadi terhambat. Tanin memiliki kemampuan sebagai inhibitor yang menghambat substrat untuk melekat pada sisi aktif enzim. Sunarno (2018) menyatakan bahwa keberadaan substrat mempengaruhi proses metabolisme dalam tubuh. Ketersediaan substrat yang rendah akan berdampak pada menurunnya produk metabolisme yang akhirnya akan mempengaruhi kinerja reproduksi dan proses pembentukan putih telur menjadi tidak optimal.

Tabel 2. Nilai HU, IKT, pH putih dan kuning telur, bobot telur, tinggi putih telur, tinggi kuning telur, dan diameter kuning telur setelah pemberian tepung daun kelor (M. oleifera)

\begin{tabular}{lccccc}
\hline \multirow{2}{*}{ Parameter } & \multicolumn{5}{c}{ Konsentrasi tepung daun kelor } \\
\cline { 2 - 6 } & $\mathbf{0 \%}$ & $\mathbf{2 , 5 \%}$ & $\mathbf{5 \%}$ & $\mathbf{7 , 5 \%}$ & $\mathbf{1 0 \%}$ \\
\hline HU & $89,34^{\mathrm{b}} \pm 2,18$ & $86,08^{\mathrm{ab}} \pm 2,64$ & $83,23^{\mathrm{a}} \pm 0,69$ & $88,68^{\mathrm{b}} \pm 1,78$ & $87,60^{\mathrm{b}} \pm 1,46$ \\
Tinggi putih (mm) & $7,88^{\mathrm{b}} \pm 0,30$ & $7,20^{\mathrm{a}} \pm 0,46$ & $7,02^{\mathrm{a}} \pm 0,23$ & $7,65^{\mathrm{ab}} \pm 0,28$ & $7,25^{\mathrm{ab}} \pm 0,32$ \\
Bobot telur (g) & $57,21 \pm 3,58$ & $56,47 \pm 3,63$ & $59,22 \pm 3,12$ & $55,81 \pm 3,41$ & $56,37 \pm 3,95$ \\
IKT & $0,44 \pm 0,02$ & $0,45 \pm 0,00$ & $0,43 \pm 0,02$ & $0,46 \pm 0,17$ & $0,45 \pm 0,49$ \\
Diameter kuning & $42,00 \pm 1,14$ & $41,72 \pm 0,36$ & $40,68 \pm 1,12$ & $40,11 \pm 0,85$ & $41,23 \pm 2,16$ \\
(mm) & & $18,96 \pm 0,23$ & $18,76 \pm 0,94$ & $18,27 \pm 0,31$ & $18,56 \pm 1,05$ \\
Tinggi kuning (mm) & $18,37 \pm 0,90$ & 16 &
\end{tabular}

Keterangan: superskrip yang berbeda pada baris yang sama menunjukkan hasil berbeda nyata $(\mathrm{P}<0,05)$. Data yang ditampilkan berupa rata-rata \pm SD.

Pemberian tepung daun kelor sebagai imbuhan pakan itik pengging tidak berpengaruh $(\mathrm{P}>0,05)$ pada bobot telur. Namun demikian, bobot telur tertinggi terdapat pada kelompok 5\%. Hal ini diduga karena kandungan mineral, protein, dan asam amino yang terdapat pada tepung daun kelor dapat dimanfaatkan oleh tubuh unggas, serta mampu meningkatkan aktivitas enzim yang berperan dalam proses sintesis telur sehingga bobot telur yang dihasilkan lebih besar meskipun tidak berbeda nyata dengan kontrol. Hal ini sesuai dengan pernyataan Lesson and Summer (2001) yang menyatakan bahwa protein dan asam amino adalah zat makanan yang paling berperan dalam mengontrol ukuran telur dan produktivitas telur. Adanya kandungan mineral pada daun kelor yang lebih besar dapat digunakan dalam meningkatkan aktivitas enzim yang terlibat dalam sintesis protein maupun proses pencernaan.

Imbuhan pakan berupa tepung daun kelor dalam pakan itik pengging tidak berpengaruh nyata $(\mathrm{P}>0,05)$ pada nilai IKT, diameter kuning telur, dan tinggi kuning telur. Hal ini diduga karena tepung daun kelor yang diberikan mengandung lignin, saponin, dan beberapa senyawa anti-nutrisi lain yang lebih tinggi, sehingga senyawa tersebut menghambat metabolisme normal dalam tubuh yang berdampak terhadap kualitas telur. Berdasarkan penelitian Ahmad et al. (2018), pemberian tepung daun kelor dapat menurunkan nilai IKT secara linier seiring dengan meningkatnya level pemberian tepung daun kelor yang diberikan. Keterbatasan dalam penggunaan aditif disebabkan oleh faktor anti-gizi, 
seperti yang ditemukan pada $M$. oleifera terdapat kandungan serat, saponin, dan banyak senyawa lainnya yang tinggi. Hal ini sejalan dengan laporan El-Sheikh et al. (2015) yang menunjukkan bahwa pemberian daun kelor pada pakan tidak memberikan perubahan pada produksi dan kualitas telur. Peningkatan konsentrasi tepung daun kelor yang diberikan pada pakan ayam dapat menurunkan nilai IKT, HU, dan tebal kerabang. Sementara itu, jika dicermati meskipun nilai IKT pada penelitian ini tidak signifikan, tetapi IKT pada kelompok itik yang diberikan imbuhan tepung daun kelor meningkat. Hal ini diduga berkaitan dengan komponen bioaktif tepung daun kelor yang dapat menstimulasi absorpsi dan metabolisme nutrisi sehingga mampu mempercepat aliran darah dan deposisi material pembentukan kuning telur menjadi lebih cepat. Berdasarkan penelitian yang dilakukan oleh Kasiyati (2017), penggunaan bahan alami mampu menstimulasi pengambilan glukosa dari intestinum dan meningkatkan pengambilan glukosa oleh sel hati dari sistem sirkulasi. Glukosa kemudian diproses menjadi beberapa bentuk, yaitu dioksidasi sebagai sumber energi, disimpan di hati sebagai glikogen, atau dikonversi menjadi asam lemak sebagai bahan baku biosintesis prekursor kuning telur.

Pemberian pakan berupa tepung daun kelor selama 3 minggu pada pakan juga tidak memberikan pengaruh yang berbeda pada $\mathrm{pH}$ kuning telur $(\mathrm{P}>0,05)$, tetapi memberikan pengaruh yang berbeda nyata pada $\mathrm{pH}$ putih telur $(\mathrm{P}<0,05)$. Kenaikan $\mathrm{pH}$ putih telur itik pengging dapat dilihat pada Gambar 1 dan kenaikan $\mathrm{pH}$ kuning telur itik pengging dapat dilihat pada Gambar 2. Hasil penelitian menunjukkan bahwa setiap penambahan konsentrasi tepung daun kelor pada pakan mampu meningkatkan nilai $\mathrm{pH}$ putih telur sehingga putih telur cenderung bersifat basa. Sebaliknya, nilai $\mathrm{pH}$ kuning telur menunjukkan hasil yang lebih stabil sehingga tidak terdapat perbedaan yang nyata pada setiap hasil perlakuan dan memberikan kondisi telur yang asam. Meningkatnya nilai $\mathrm{pH}$ putih dan $\mathrm{pH}$ kuning telur sejalan dengan peningkatan konsentrasi tepung daun kelor yang ditambahkan ke dalam pakan. Agustina (2013), menyatakan bahwa nilai pH kuning telur segar sekitar 6,0 dan akan meningkat secara perlahan menjadi 6,8 sedangkan untuk nilai pH putih telur segar sekitar 7,6-7,9 dan akan mengalami peningkatan secara maksimal menjadi 9,6 .

Hasil analisis pemberian tepung daun kelor mampu meningkatkan nilai $\mathrm{pH}$ putih telur. Nilai $\mathrm{pH}$ putih telur pada perlakuan kelor $10 \%$ meningkat sebanyak $8,66 \%$ jika dibandingkan dengan $\mathrm{pH}$ putih pada perlakuan kontrol. Hal ini diduga karena kandungan bioaktif pada daun kelor belum mampu mempengaruhi kondisi fisik telur sehingga telur kehilangan $\mathrm{CO}_{2}$ dan menjadi lebih encer. Faktor lain dari perubahan $\mathrm{pH}$ diantaranya suhu lingkungan yang mampu menyebabkan cepat atau lambatnya penguapan air pada telur. Jazil et al. (2013) menyatakan hilangnya $\mathrm{CO}_{2}$ melalui pori kerabang telur mengakibatkan konsentrasi ion bikarbonat dalam putih telur menurun dan merusak sistem buffer, sehingga meningkatkan $\mathrm{pH}$ telur. Hal lain yang menyebabkan meningkatnya $\mathrm{pH}$ putih telur diduga karena daun kelor kering mengandung kalsium dan asam amino yang tinggi. Tingginya kandungan kalsium pada daun kelor ini diduga mempengaruhi sintesis albumen telur, sehingga albumen telur menghasilkan sifat basa.

Hasil analisis pemberian tepung daun kelor pada $\mathrm{pH}$ kuning telur tidak memberikan pengaruh yang nyata, hal ini diduga karena protein dan asam amino yang terkandung di dalam daun kelor mampu mempertahankan kualitas $\mathrm{pH}$ dari kuning telur tersebut. Protein dan asam amino mampu mempertahankan kekuatan ikatan ovomusin, sehingga hilangnya air dan $\mathrm{CO}_{2}$ pada putih telur dapat ditekan, dan kuning telur tidak cepat mengalami pengenceran dan perubahan $\mathrm{pH}$. Perubahan $\mathrm{pH}$ kuning telur terjadi secara perlahan, dikarenakan vikositas kuning telur yang lebih stabil.

Faktor-faktor yang mempengaruhi nilai $\mathrm{pH}$ telur antara lain umur telur, suhu, dan penyimpanan telur. Kenaikan $\mathrm{pH}$ telur disebabkan karena adanya transfer $\mathrm{CO}_{2}$ dan air melalui poripori kerabang telur. Kerusakan serabut ovomusin juga menyebabkan $\mathrm{pH}$ telur menjadi meningkat ditandai dengan mencairnya putih telur dan semakin lebarnya diameter kuning telur (Riawan dkk., 2017). Berdasarkan laporan Reijrink et 
al. (2008), nilai $\mathrm{pH}$ albumen yang meningkat hingga 9 bertujuan untuk melindungi embrio dari kontaminasi mikroba. Peningkatan $\mathrm{pH}$ albumen bergantung pada kapasitas buffer yang terdapat pada albumen, suhu, waktu penyimpanan, temperatur penyimpanan dan kondisi kulit telur.
Berdasarkan hasil penelitian, diketahui bahwa tanaman kelor $(M$. oleifera) dapat memberikan pengaruh pada kualitas fisik telur sehingga dapat dimanfaatkan dalam bidang peternakan sebagai bahan pakan untuk pengembangan budi daya itik pengging.

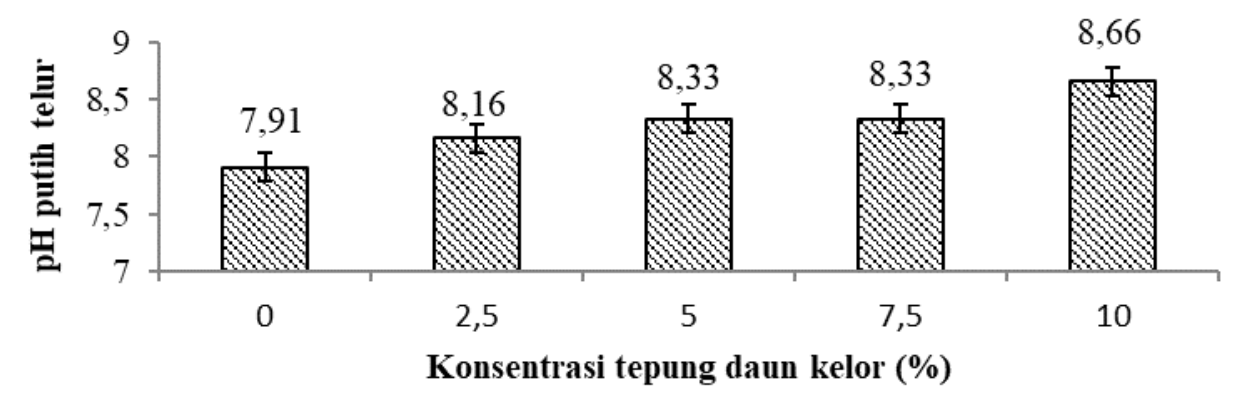

Gambar 1. pH putih telur pada itik pengging yang diberikan imbuhan tepung daun kelor dalam pakan. Terdapat perbedaan yang nyata $(\mathrm{P}<0,05)$ antara kelompok kontrol $(0 \%$ tepung daun kelor $)$ dengan kelompok 2,$5 ; 5,7,5 ;$ dan $10 \%$. Data yang ditampilkan berupa rata-rata \pm SE.

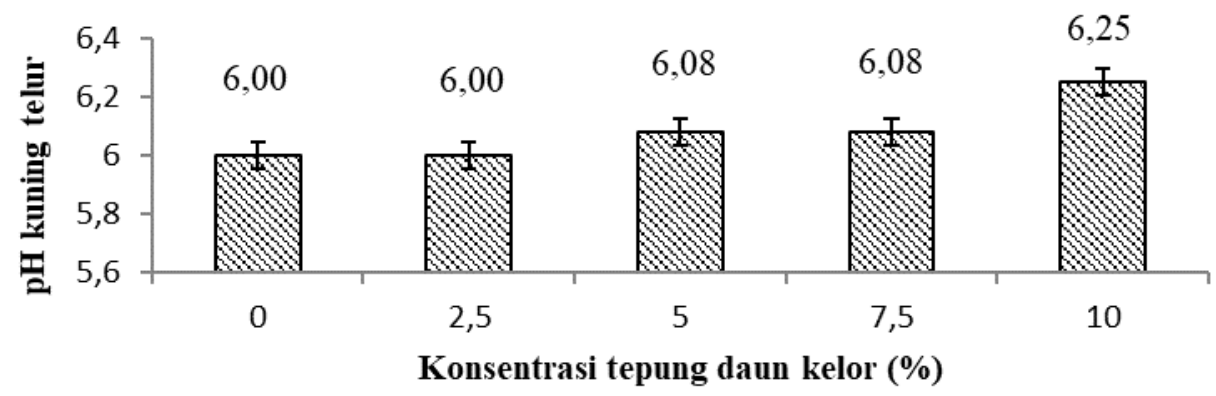

Gambar 2. pH kuning telur pada itik pengging yang diberikan imbuhan tepung daun kelor dalam pakan. Imbuhan tepung daun kelor tidak berbeda nyata $(\mathrm{P}>0,05)$ pada $\mathrm{pH}$ kuning telur. Data yang ditampilkan berupa rata-rata \pm SE.

\section{KESIMPULAN}

Pemberian tepung daun kelor (M. oleifera) sebagai imbuhan pakan pada itik pengging tidak menyebabkan perubahan pada kualitas fisik telur, yang meliputi nilai HU, IKT, dan $\mathrm{pH}$ telur. Tepung daun kelor sebagai imbuhan pakan dapat digunakan pada itik hingga konsentrasi $10 \%$.

\section{DAFTAR PUSTAKA}

Agustina, N., Thohari, I., dan D. Rosyidi. 2013. Evaluasi sifat putih telur ayam pasteurisasi ditinjau dari $\mathrm{pH}$, kadar air, sifat emulsi dan daya kembang angel cake. Jurnal Ilmuilmu Peternakan, 23(2): 6-13
Ahmad, S., Khalique, A., Pasha, T. N., Mehmood, S.,Hussain, K., Ahmad, S., Shaheen, M. S., Naeem, M., and M. Shafiq. 2017. Effect of Moringa oleifera (Lam.) pods as feed additive on egg antioxidants, chemical composition and performance of commercial layers. South African Journal of Animal Science, 47 (6): 864-874

Ahmad, S., Khalique, A., Pasha, T. N., Mehmood, S., Sohail, A. S., Khan, A. M., and K. Hussain. 2018. Influence of Moringa oleifera leaf meal used a phytogenetic feed additive on the serum metabolites and eggs bioactive compounds in commercial layers. Brazilian Journal of Poultry Science, 20(2): 325-332 
Aminah, S., Ramdhan, T., dan M. Yanis. 2015. Kandungan nutrisi dan sifat fungsional tanaman kelor (Moringa oleifera). Buletin Pertanian Perkotaan, 5(2): 35-44

Badan Standar Nasional (BSN). 2008. Telur Ayam Konsumsi. BSN, Jakarta

Chumark, P., Khunawat, P., Sanvarinda, Y., Phornchirasilp, S., Morales, N. P., Phivthong-Ngam, L., Ratanachamnong, P., Srisawat, S., and K. U. Pongrapeeporn. 2007. The in vitro and ex vivo antioxidant properties, hypolipidaemic and antiatherosclerotic activities of water extract of Moringa oleifera Lam. leaves. Journal of Ethnopharmacology, 116: 439446

Ditjen PKH. 2017. Statistik Petenakan dan Kesehatan Hewan (LiveStock and Animal Helath Statistic) 2017. Kementerian Pertanian RI, Jakarta

El-Sheikh, N. I., El-Shazly, E. S., Abbas, E. A., and L. A. El-Globary. 2015. Effect of Moringa leaves on lipid content of table eggs in layer hens. Journal of Chemistry and Environment Healt, 1(1): 291-302

Gilani, G. S., Cockell, K. A., and E. Sepehr. 2005. Effect of antinutritional factors on protein digestibility and amino acid availability in foods. Journal of AOAC International, 88(3): 967-989

Griffiths, D. W. 1986. The inhibition of digestive enzymes by polyphenolic compounds. Journal Advances in Experimental Medicine and Biology NCBI, 199: 509-516

Ismoyowati. 2008. Detection of egg production of tegal duck by blood protein polymorphisme. Journal Animal Production, 10(2): 122-128.

Jazil, N., Hintono A., dan Mulyani . 2012. Penurunan kualitas telur ayam ras dengan intensitas warna cokelat kerabang berbeda selama penyimpanan. Skripsi. Universitas Diponegoro, Semarang

Kasiyati. 2017. Suplementasi kurkumin dan peran cahaya monokromatik untuk mengoptimalkan biosintesis telur itik lokal. Disertasi. Institut Pertanian Bogor, Bogor

Kasiyati, Djaelani, M. A., and Sunarno. 2019. Effect of Suplementation of Moringa oleifera Leaf powder on Reproductive Performance and Ovarium Morphometry of Pengging Duck. International Journal of Poultry Science. In press

Kwari, I. D., Diarra, S. S., Raji, A. O., and S. B. Adamu. 2011. Egg production and egg quality laying hens fed raw or prosessed sorrel (Hibiscus sabdariffa) seed meal. Agriculture And Biology Journal of North America, 2(4): 616-621

Leeson, S. and Summers. 2001. Nutritient of The Chicken $4^{\text {th }}$ edition. University Book, Canada

Minieri, S., Buccioni, A., Serra, A., Aligani, I. G., Pezzati, A., Rapaccini S., and M. Antongiovanni. 2016. Nutritional characteristics and quality of eggs from laing hens fed on a diet supplemented whit chestnut tannin extract (Castanea sativa Miller). British Poultry Science, 57(6): 824-832.

Misra, A., Srivastava, S., and M. Srivastava. 2014. Evaluation of anti diarrheal potential of Moringa oleifera leaves. Journal of Pharmacognosy and Phytochemistry, 2(5): 43-46

Nugraha, F. S., Mufti, M., dan H. Ibnu. 2013. Egg duck quality that was rear on wet pen and dry pen in cirebon regency. Jurnal Ilmiah Peternakan, (2): 726-734

Purwati, D., Djaelani, M. A., dan Y. W. Y. Eny. 2015. Indeks kuning telur (IKT), haugh unit (HU) dan bobot telur pada berbagai itik lokal di jawa tengah. Jurnal Biologi, 4(2): $1-9$

Reijrink, I. A. M., Meijerhof, R., Kemp, B., and H. V. D. Brand. 2008. The chicken embryo and its micro environment during egg storage and early incubation. World Poultry Science Journal, 64: 581-598

Riawan, Riyanti, dan K. Nova. 2017. Pengaruh perendaman telur menggunakan larutan 
daun kelor terhadap kualitas internal telur ayam ras. Jurnal Ilmiah Peternakan Terpadu, 5(1): 1-7

Saraswati, T. R., and S. Tana. 2016. Effect of turmeric powder supplementation to the age of sexual maturity, physical, and chemical quality of the first japanese quail's (Coturnix japonica) egg. Journal of Biosaintifika, 8(1):18-24

Sudaryani, T. 2006. Kualitas Telur. Penebar Swadaya, Jakarta.

Sunarno. 2018. Efek suplementasi kulit kayu manis dan daun pegagan terhadap produktivitas puyuh petelur strain australia (Conturnix conturnix australica). Buletin Anatomi dan Fisiologi, 3(1): 89-96.

Susetyarini, E. 2013. Aktivitas tanin daun beluntas terhadap konsentrasi spermatozoa tikus putih jantan. Jurnal Gamma, 8(2): 14-20

Tamir, M., and E. Alumot. 1969. Inhibition of digestive enzyme by condensed tannins from green and ripe carobs. Journal of Science of Food and Agriculture, 20(4): 199-202

United States Department of Agriculture. 2000. Egg Grading Manual. Department of Agriculture, Washington

Yameogo, W. C., Bengaly, D. M., Savadogo, A., Nikiẻma, P. A., and S. A. Traorẻ. 2011. Determination of chemical compositionand Nutritional values of Moringa oleifera leaves. Pakistan Journal of Nutrition, 10(3): 264-268 